\title{
Production and chemical characteristics of the populations of spring garlic (Allium Sativum L.) from the serbian genetic collection
}

\author{
Djordje Moravčevićc ${ }^{*}$, Jelica Gvozdanović Varga ${ }^{2}$, Nenad Pavlović ${ }^{3}$, Vida Todorović4, Milan Ugrinović ${ }^{3}$ \\ ${ }^{1}$ University of Belgrade, Faculty of Agriculture, Nemanjina 6, 11080 Zemun, Republic of Serbia, ${ }^{2}$ Institute of Field and Vegetable Crops, \\ Maksima Gorkog 30, 21000 Novi Sad, Republic of Serbia, ${ }^{3}$ Institute for Vegetable Crops, Karađorđeva 71, 11420 Smederevska Palanka, \\ Republic of Serbia, ${ }^{4}$ Faculty of Agriculture, University of Banja Luka, Bulevar Vojvode Petra Bojovića 1 A, 78000 Banja Luka, Bosnia and \\ Herzegovina
}

\section{A B S TR A C T}

A great number of spring garlic populations are present in Serbia. It is a very heterogeneous biological material. To date, it has been little studied. Therefore, the aim was to study its production and chemical characteristics. Eighteen populations of spring garlic were examined. Most of the production of this garlic in Serbia is based on them. They were examined in Zminjak, which is located in the central Mačva (Serbia). The method of field experiments was used. The research lasted for three years. The results comprise two groups of parameters. The first group contains the results which show the most important productive characteristics (weight of bulb, number of cloves per bulb, bulb yield). The second group consists of the parameters for chemical characteristics of the investigated populations (dry matter, etheric oil, and alliin). In this case, the populations demonstrated a significant influence, and their stability was also very conspicuous. Most of the investigated populations of spring garlic can serve as a good resultant material for obtaining new cultivars. The populations can be classified as follows: SG-18, SG-25, SG-28, SG-16, SG-29 (yield), SG-21, SG-26 (technological quality) and SG-29, SG-18, SG-16 (foodstuff and pharmaceutical quality). They can remain as populations, but it would be significantly better to create new cultivars by using them.

Keywords: Alliin; Etheric oil; Garlic; Population; Yield

\section{INTRODUCTION}

The primary centre of origin of garlic is Central Asia, i.e., its highland area ranging from Afghanistan, throughout Northwest India, Tajikistan and Kyrgyzstan, and to a lesser degree the territory of China (to the Taklamakan desert), Kazakhstan, Uzbekistan and Turkmenistan. From this area it has spread throughout the world. It has been used as a cultivar for several thousand years. Garlic was considered to have lost its ability of generative reproduction during cultivation. However, in the last century, ecotypes with fertile seeds were found in the territory of Kazakhstan (Brewster, 2008). The secondary centre of origin of garlic is the Mediterranean region.

China is the largest producer of garlic in the world, containing around $58 \%$ of the total world areas with garlic $(856,500 \mathrm{ha})$.
Owing to its high average annual yield (above $23 \mathrm{t} \mathrm{ha}^{-1}$ ), China accounts for $81 \%$ of the global output of garlic. The global yield of garlic $\left(16.3 \mathrm{tha}^{-1}\right)$ is two times larger than the yield obtained in Europe. In Serbia, the production of garlic is modest and is maintained on the area of 7,600 ha, with the average yield of approximately $2.5 \mathrm{tha}^{-1}$ (FAO, 2015). Serbia imports garlic in order to satisfy its demands.

Garlic (Allium sativum L.) is a diploid species in the Allium genus of the Alliaceae family, order Asparagales. There are two subspecies within the species: ssp. sativum - common garlic and ssp. asiae mediae - Central Asian garlic. Each subspecies consists of two varieties: var. vulgare - common (nonbolting) and var. sagitatum - bolting garlic (Kazakova, 1978). Var. vulgare, including the subtypes of spring and autumn garlic, is more significant to us. The production of garlic in Serbia is based on these two subtypes.

\footnotetext{
${ }^{*}$ Corresponding author:

Djordje Moravčević, University of Belgrade, Faculty of Agriculture, Nemanjina 6, 11080 Zemun, Republic of Serbia.

E-mail: djordje.moravcevic@gmail.com
}

Received: 19 November 2016;

Revised: 04 February 2017;

Accepted: 05 February 2017;

Published Online: 15 February 2017 
Due to its intensive aroma and characteristic flavour, garlic is primarily used as spice. It is taken fresh in small quantities, so it is treated as the vegetable in the narrow sense. It has high nutritive value, although this has small significance since only small quantities are taken via food. It has a high percentage of dry matter ranging from $33 \%$ to $45 \%$. It is mostly made of sugars (20-30\%), proteins (5-6\%), fibres, vitamins, amino acids, minerals $(1-1,5 \%)$. Garlic is specific for containing essential oil (0.15-0.75\%) (Haciseferogullari et al., 2005; Kimbaris et al., 2006). The basis of this oil is sulfur-containing compounds. More than $2 / 3$ of the total sulfur is in the form of alkylcysteine sulfoxide and $\gamma$-glutamyl peptide (Lawson, 1996). The garlic cells contain alkylcysteine sulfoxide, alliin, isoalliin and methiin. Crushing the cells leads to their transformation, under the impact of the enzyme alliinase, into thiosulfinates, $70-80 \%$ of which is the compound of allicin. The characteristic aroma and flavour of garlic stems primarily from allicin (alliin), and this is the basis of the healing properties of garlic (Lanzotti, 2006; Song et al., 2007).

Garlic has been used as a medicine since ancient times. It is useful for the reduction of blood pressure, cholesterol, arteriosclerosis. It has potent antibacterial and antifungal activities. It stimulates the release of bile and normalizes liver function. It is also widely applied externally, for bandages on infected wounds, ulcers, calluses, cuts. As a supplement it can be found in the form of tablets, capsules, tinctures and other preparations (Kamenetsky et al., 2005; Božin, 2009).

In Serbia, garlic is produced in an extensive manner, so it gives extremely low yields. Extensivity is mostly caused by using poor planting material and applying incomplete agrotechnical measures. Garlic is multiplied only by vegetative reproduction (using cloves), so large quantities of quality declared planting material are necessary for the production. Such garlic is scarce on the Serbian market. Thus, the production is mostly based on domestic populations or the consumable garlic imported from the neighbouring countries (Hungary, Bulgaria, Albania).
The objective of this paper is to examine domestic garlic populations thoroughly and to recommend them for further selection and production.

\section{MATERIAL AND METHODS}

\section{Field experiments and plant material}

The populations of garlic were studied in the territory of Western Serbia (Mačva), the village of Zminjak, the municipality of Šabac $\left(44^{\circ} 45^{\prime} 17,66^{\prime \prime}\right.$ N, $19^{\circ} 28^{\prime} 15,44^{\prime \prime}$ E, and 87 m.a.s.l). The method of field experiments was used, which were set in the random block design with four repetitions. The elementary plot size was $4 \mathrm{~m}^{2}(2 \times 2 \mathrm{~m})$. The experiments were conducted during the period of three years. Eighteen populations of spring garlic were examined, collected in the territory of Serbia and registered in the National Plant Gene Bank. Each population has its own code and place of origin in the mentioned bank (Table 1).

The experiments were set up in March. Starting from the first to the final year, the setting up was conducted on March $19^{\text {th }}, 16^{\text {th }}$ and $20^{\text {th }}$, respectively. The spacing between planted cloves was $25 \times 10 \mathrm{~cm}$. Thus, the crop density amounted to 40 plants per $\mathrm{m}^{2}$. Standard agrotechnical measures were applied.

Garlic was ready for harvesting (pulling out) in July. The time for pulling out was determined according to the appearance of the plants, i.e., it was waited for the pseudostem to soften completely and thus to avoid lodging of the crops (July $17^{\text {th }}, 14^{\text {th }}$ and $23^{\text {rd }}$ ). The removed garlic was dried additionally in a natural manner on the field (approximately 7 days), and then transported into the appropriate space (under the eaves).

\section{Production and chemical characteristic}

The production and chemical characteristic of garlic (populations) were defined in January using the stored garlic (six months after the harvest), and they are the following: the bulb weight, the number of cloves per

Table 1: Population of spring garlic

\begin{tabular}{|c|c|c|c|c|c|}
\hline \multirow[t]{2}{*}{ Code number } & \multicolumn{2}{|l|}{ Location } & \multirow[t]{2}{*}{ Code number } & \multicolumn{2}{|l|}{ Location } \\
\hline & Municipality & Village & & Municipality & Village \\
\hline SG-1 & Knjaževac & Debelica & SG-19 & Negotin & Kobišnica \\
\hline SG-2 & Bujanovac & Beli Breg & SG-20 & Preševo & Oraovica \\
\hline SG-6 & Bela Palanka & Dolac & SG-21 & Vranje & Pavlovac \\
\hline SG-8 & Lebane & Prekopčelica & SG-22 & Bujanovac & Žbevac \\
\hline SG-12 & Šabac & Zminjak & SG-25 & Negotin & Rečka \\
\hline SG-15 & Valjevo & Valjevska Loznica & SG-26 & Vladimirci & Debrc \\
\hline SG-16 & Ljig & Brančić & SG-27 & Negotin & Radujevac \\
\hline SG-17 & Valjevo & Valjevska Loznica & SG-28 & Negotin & Rečka \\
\hline SG-18 & Rača & Miraševac & SG-29 & Negotin & Rečka \\
\hline
\end{tabular}


bulb, the bulb yield, as well as the content of dry matter, essential oil and alliin. The samples containing 40 bulbs were used (with the exception of the yield). The precise scales were used for determining the bulb weight, and the unit of measurement was gram [g]. Following the previous measurement (the bulb weight), the separation of the bulbs into cloves ensued, and their number per bulb was obtained by counting. The bulbs from each plot were measured for determining the yield, and the obtained values were used when calculating the yield per unit of area $\left(\mathrm{kg} \mathrm{ha} \mathrm{h}^{-1}\right)$. Chemical characteristics of garlic (bulbs) were studied in the laboratory. The total dry matter was determined using the gravimetric method of drying the garlic in the dryer at $105^{\circ} \mathrm{C}$ for two hours and is presented in the form of percentages $[\%]$. In order to determine the content of essential oil, the method of hydrodistillation according to Clavenger was used (European Pharmacopoeia IV). This content is provided in the form of percentages (g $100 \mathrm{~g}^{-1}$ of fresh material). The organosulfur compound of alliin was determined using a High Performance Liquid Chromatography (HPLC) method. (Lawson and Gardner, 2005). The results are provided as percents [\%].

\section{Data analysis}

The obtained results were analyzed using the descriptive and analytic statistics. The arithmetic mean $(\overline{\mathrm{x}})$, maximum ( $\max )$ and minimum ( $\mathrm{min}$ ) values and the coefficient of variation $(\mathrm{Cv}, \%)$ were defined. Within the analytic statistics, the data were processed using the model of two-factor analysis of variance, while the individual comparison of groups was performed by the later LSD test. The data were processed by various mathematical and statistical programs (Microsoft Office Excel 2007, Statistika and DSAASTAT) and are presented in the form of tables and figures.

\section{RESULTS AND DISCUSSION}

\section{Climate and soil conditions}

The analysis of climate conditions was conducted using the data of the Republic Hydrometeorological Service of Serbia (Fig. 1) from the meteorological station Sremska Mitrovica (44 $58^{\prime} \mathrm{N}$; $19^{\circ} 38^{\prime} \mathrm{E}$; 81 m.a.s.l).

The soil used in the experiments was chemically tested. Active acidity of the soil ( $\mathrm{pH}$ in water) was measured in the soil suspension with water using a potentiometer, $\mathrm{pH}$ meter, while the potential soil acidity $(\mathrm{pH}$ in $1 \mathrm{M} \mathrm{KCl})$ was measured in the soil suspension with potassium chloride. Free calcium-carbonate $\left(\mathrm{CaCO}_{3}\right)$ was determined volumetrically using the Scheibler calcimeter and is expressed in percentages (ISO 10693:1995). The content of humus was obtained through the oxidation of organic matter using the Turin method (Simakov's modification) and is presented in percents [\%]. The total nitrogen (N) was obtained by the Kjedahl method and is also presented in the form of percents [\%]. Phosphorus pentoxide $\left(\mathrm{P}_{2} \mathrm{O}_{5}\right)$ was examined using spectrophotometric methods, and potassium $\left(\mathrm{K}_{2} \mathrm{O}\right)$ using a flame photometer. The content is provided in $\mathrm{mg} 100 \mathrm{~g}^{-1}$ of soil (Đžamić et al., 1996).

The experiments were set on the Cambisol type of soil, more precisely the Cambisol undergoing podzolization. According to its chemical characteristics, the soil where the experiment was conducted can be considered suitable for agricultural production. It belongs to the group of acid soils (potential acidity - 4.9), where the content of calcium-carbonate is extremely low and does not exceed $0.5 \%$ (poorly calcareous soil). The content of humus in the plough layer is medium $(1.6 \%)$, while its content in the depth of 30 to $60 \mathrm{~cm}$ is low $(0.42 \%)$. The classification is identical as regards the total content of nitrogen. The presence of phosphorus pentoxide in the soil is low and extremely low (7.814.6 mg $100 \mathrm{~g}^{-1}$ of the soil). Smaller quantities of phosphorus were recorded in deeper layers. The soil has the medium to high presence of the accessible potassium (14.3-30.1 mg $100 \mathrm{~g}^{-1}$ of the soil). Similarly to phosphorus, smaller quantities of potassium were recorded in deeper layers. These properties make the soil favourable for agricultural production (Živković, 1991).

\section{Production characteristic}

The three-year average value for the bulb weight of the examined garlic populations was $14.29 \mathrm{~g}$. The lowest value was recorded for the population SG-1, and the highest for the population SG-18 (Fig. 2). These were 12.8 and $17.1 \mathrm{~g}$, respectively. The value similar to the minimum value was realized by three populations (SG-26, SG-2 and SG-27). The maximum realized value differed significantly from the other average values. A similar value of the bulb weight of the SG-25 population $(15.5 \mathrm{~cm})$ was also significantly higher than the remaining populations. According to the value

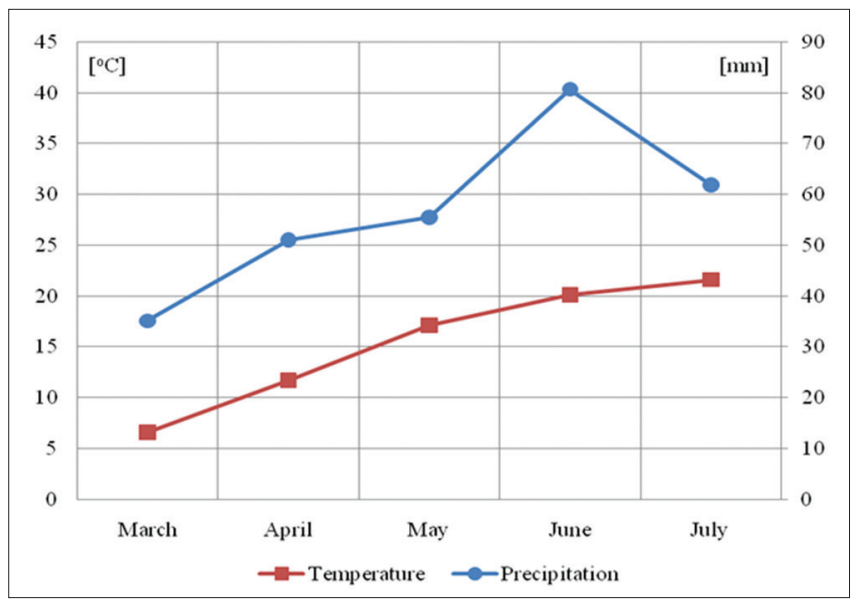

Fig 1. Climate diagram according to Walter, multi-year average (Sremska Mitrovica). 
for this characteristic, these remaining populations can be divided into three groups. Three populations had the bulb weight in the range from 13.5 to $13.8 \mathrm{~g}$, five populations had the range from 14.2 to $14.6 \mathrm{~g}$, while four populations had the average bulb weight from 14.8 to $15.1 \mathrm{~g}$. Within these groups the average values of the bulb weight did not differ, while the differences in these values between the groups were significant. The coefficient of variation for the bulb weight in the complete experiment had the value of $15.7 \%$. The lowest value of this coefficient was realized by the population SG-21, while the highest was reached by the population SG-8. These values were 10.2 and $21.71 \%$, respectively. The absolute minimum value of the bulb weight realized in the experiment was $8.6 \mathrm{~g}$, while the maximum bulb weight amounted to $24.6 \mathrm{~g}$. The former was part of the sample of the population SG-12, while the latter belonged to the population SG-18.

The bulb weight is the parameter which has the most direct impact on garlic yield. It represents the most significant production characteristics of garlic, defining the yield and its market value. The bulb weight is influenced by agro-ecological conditions, cultivars and agrotechnology (Ahmad and Iqbal, 2002; Moravčević et al., 2011). In comparison with yield and number of cloves, the variation in the weight bulb is least determined by genotype (Mahmood et al., 2002). The differences for this parameter caused by genotype (population) were observed in our research. Regarding the bulb weight, the promising and stable populations are prominent and they can be used in the production and further selection. The populations SG-18 and SG-25 should be highlighted; they had the largest bulb in the multi-year average. This is indicated by the coefficients of variation obtained in our research which are in accordance with other studies of pre-selection material (Islam et al., 2004). In addition, there are numerous studies which highlight the high correlation between the bulb weight and other production properties of garlic, particularly with the number of cloves in a bulb, the bulb radius and yield (Figliuolo et al., 2001).

During three-year-long examining of garlic, the average number of cloves per bulb for all populations was 8.4. The population SG-27 had the lowest number of cloves, while the population SG-1 had the highest value. These values were 6.3 and 11.8 (Fig. 3). Generally, the populations differ significantly according to the values of the observed characteristic. The differences are not significant only between the populations whose values for the number of cloves are very similar. Thus, the garlic SG-26 with the number of cloves of 6.4 does not differ significantly from the garlic SG-27 (6.3). The average number of cloves of 6.8 was recorded in the population SG-20 and it differs significantly from the average values of other garlic populations. These differences are characteristic of the populations SG-25 and SG-1 (9.2 and 11.8, respectively). The remaining average values of this parameter were defined by the populations in several groups with the maximum of 3 members. The average coefficient of variation had the value of $10.7 \%$. This coefficient ranged from 7.9 to $17.9 \%$ (SG-25 and SG-12). The absolute maximum number of cloves was recorded within the sample of the SG-12 population (15 cloves), while the population SG-26 had the absolute minimum (4 cloves).

The spring garlic bulb contains more cloves than the autumn garlic. These cloves are smaller and make a compact,

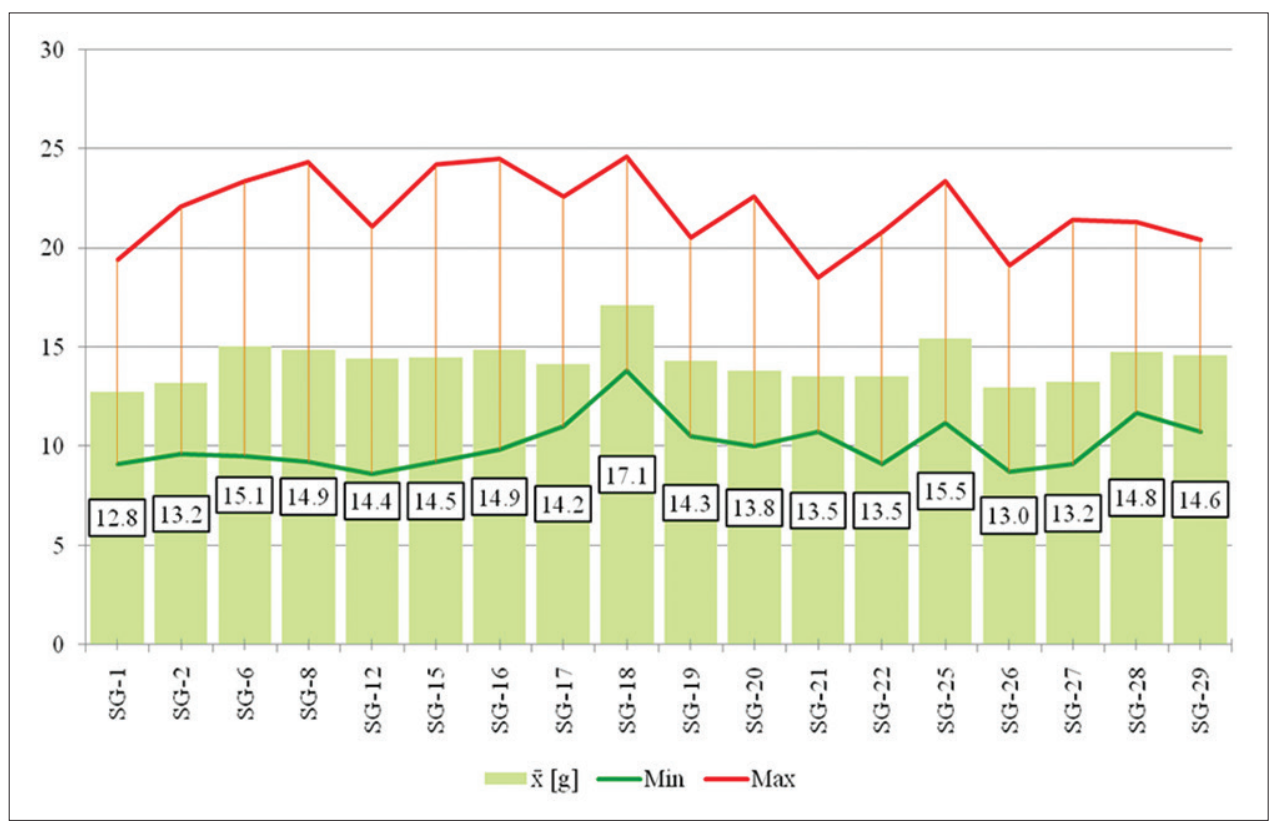

Fig 2. Weight of the bulb $[g]$, multi-year average. $(\operatorname{LSD}(0.05)=0.44 ; \operatorname{LSD}(0.01)=0.57 ; \mathrm{Cv}(\%)=15.7)$. 
compressed bulb (Etoh and Simon, 2002). Each individual clove consists of a germ and a juicy non-assimilating leaf. Germs are formed in the axil of the leaves, and their arrangement corresponds to the arrangement of the leaves. According to the number of cloves, there are cultivars with weak branching (3-6 cloves), medium branching (7-15) and strong branching (more than 15). The number of cloves per bulb depends on the genotype and the conditions of garlic growth, as well as on the temperature of the planting material storage (Mahmood et al., 2002). On the basis of the criteria of DUS testing, the number of cloves per bulb can be low $(<10)$, medium (11-20) and high $(>20)$. In our research, genotype (population) had a significant impact on this production characteristic. A larger number of cloves per bulb were realized in the years with unfavourable weather conditions, which is consistent with the findings of other studies (Islam et al., 2004; Panthee et al., 2006; Moravčević et al., 2011). Similarly, larger bulbs had a smaller number of more uniform cloves in our studies (Figliuolo et al., 2001; Baghalian et al., 2006).

The bulb yield of the observed garlic populations had the three-year average value of $3,617 \mathrm{~kg} \mathrm{ha}^{-1}$. The average yield varied between the values of 3,055 and 4,968 kg (Fig. 4).

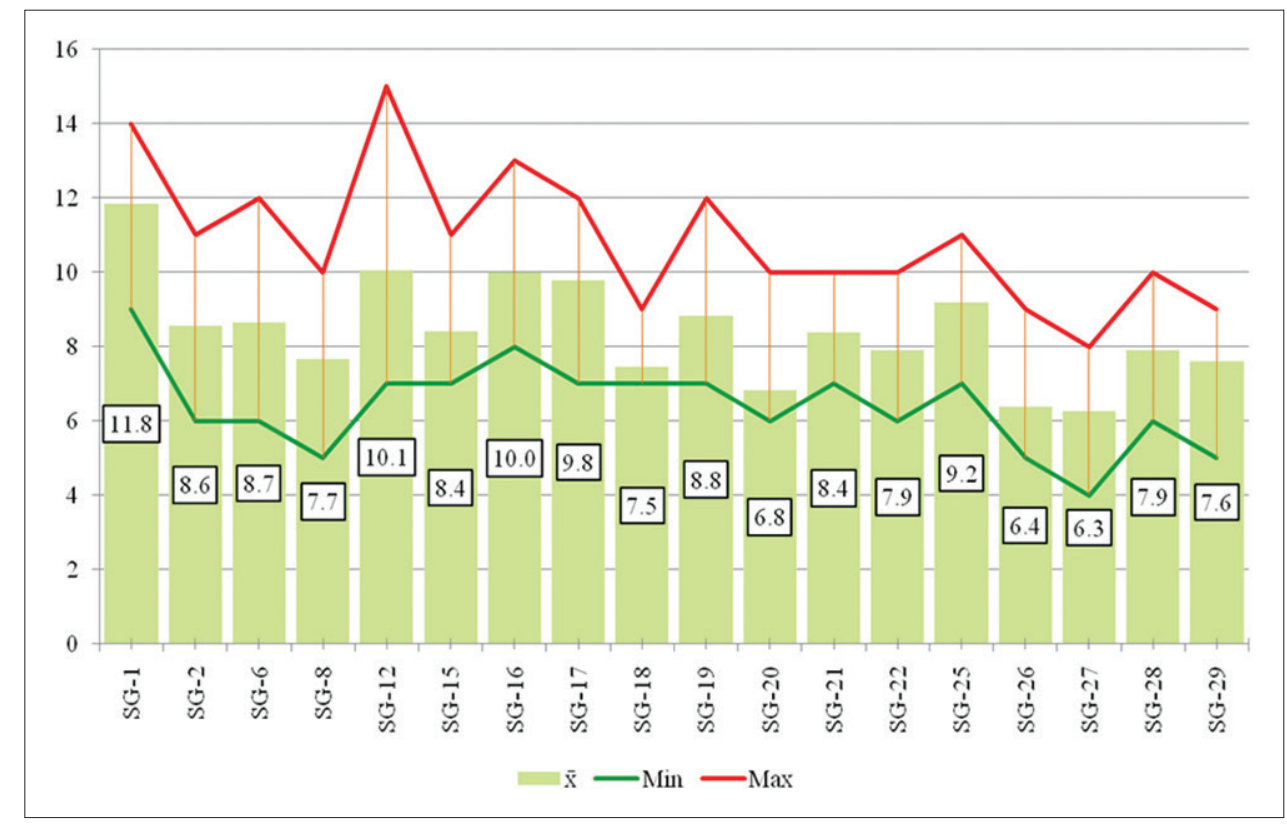

Fig 3. Number of cloves per bulb, multi-year average. $(\operatorname{LSD}(0.05)=0.19 ; \operatorname{LSD}(0.01)=0.26 ; \mathrm{Cv}(\%)=10.7)$.

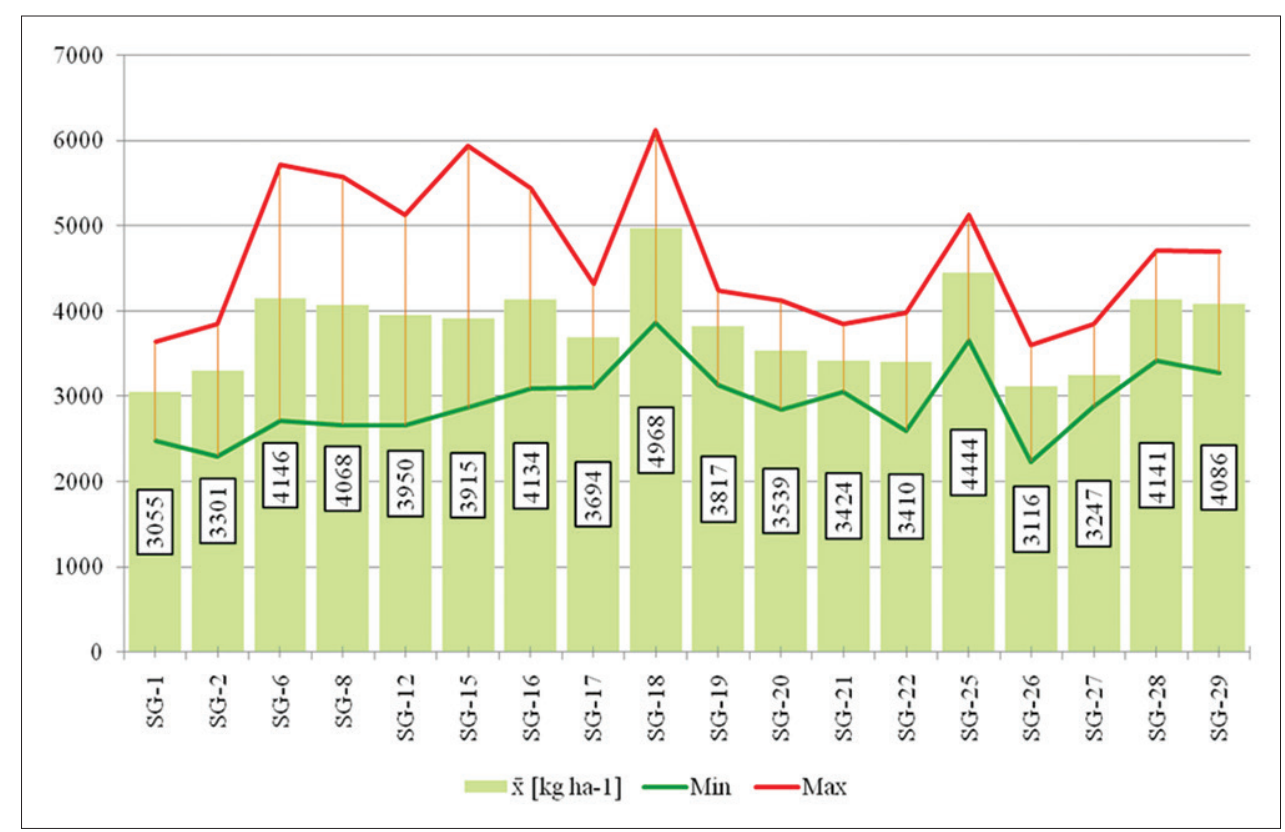

Fig 4. Bulb yield [kg ha-1], multi-year average. $(\operatorname{LSD}(0.05)=221 ; \operatorname{LSD}(0.01)=292 ; \mathrm{Cv}(\%)=15.1)$. 
These marginal values were realized by the populations marked as SG-1 and SG-18. Namely, the bulb yield of the populations SG-26 and SG-27 (3,116 and 3,247 kg ha $\left.{ }^{-1}\right)$ did not significantly differ from the minimum $(3,055 \mathrm{~kg} / \mathrm{ha})$. However, they differed significantly from other populations. Furthermore, the maximum yield value, as well as the next value recorded in the garlic SG-25 $(4,444 \mathrm{~kg})$, differed significantly from the remaining values of this property. According to the yield values which did not statistically significantly differ, the populations were classified into several groups. As a result, the most numerous was the group of the garlic types whose yield per hectare ranged from 4,068 to 4,146 kg. There were 5 populations of this kind. In addition, a group of 3 populations had the values of yield in the range from 3,817 to $3,950 \mathrm{~kg}$. Therefore, when the garlic yields from these different groups were compared, significant differences were noticed. First, the coefficient of variation of this parameter had the value of $15.1 \%$ for the whole experiment. Second, the lowest $\mathrm{Cv}(6.3 \%)$ was recorded within the population SG-21 and highest $\mathrm{Cv}(26.2 \%)$ was recorded within the population SG-8. Third, the bulb yields of 2,231 and $6,125 \mathrm{~kg} \mathrm{ha}^{-1}$ represented the absolute minimum and maximum values (SG-26 and SG-18).

Intensive production of garlic, as well as of other agricultural species, aims to make maximum yield per unit of area. Thus, manifestation of the genetic potential of plants is directly correlated with the agro-economical conditions and the applied agrotechnology (Rekowska and Skupien, 2007; Mirzaei et al., 2007; Brewster, 2008; Moravčević et al., 2011). Depending on the genotype, the bulb yield of garlic can vary significantly, and it is primarily influenced by the quality of soil and climate (Cortes et al., 2003). Importantly, the stabilization of the properties of the introduced garlic genotypes lasts for the minimum period of three years (Kamenetsky et al., 2004; Burba, 2009; Mathew et al., 2011). Obviously, large variations of this parameter in our research indicated the variety of the studied material. The average values of the realized bulb yield per population were high. In particular, some populations offered significantly higher yield, primarily the garlic marked SG-18. This garlic had high values for the other studied morphological and production characteristics, indicating that there was a significant correlation between these characteristics. Similarly, numerous researchers have pointed at this yield behaviour (Panthee et al., 2006; Pardo et al., 2007; Zahedi et al., 2007). In order to examine the garlic quality more thoroughly, in addition to yield, the bulb weight and shape index, as well as the number and weight of bulb cloves, should be considered (Rahman et al., 2004). Taking this into accoint, we may claim that that the bulbs labelled SG-18, SG-25 i SG-28 were of the highest quality in our experiment.

\section{Chemical characteristics}

The average three-year value of dry matter content in the bulb for all the populations was $38.9 \%$. The lowest average value of this parameter was recorded in the population SG-19, and the highest in the populations SG-26 and SG-21. These values were 37.4 and $40.2 \%$, respectively (Fig. 5). Three observed populations had the values of dry matter content from 37.4 to $37.6 \%$. These values were not statistically different. According to this principle, several additional groups were noticed. The most interesting and most numerous group (5 populations) was the one whose populations had the values of dry matter from 39.0 to $39.3 \%$. Importantly, the populations from different groups realized significantly different dry matter content. The average coefficient of variation for the complete experiment was $3.1 \%$. The realized $\mathrm{Cv}$ in the population SG-22 had the lowest value $(1.9 \%)$, while the population SG-16 had the highest value (4.1\%) for this coefficient. Furthermore, the absolute minimum of dry content amounts to $34.7 \%$ and was measured in the sample of the SG-16 garlic. On the other hand, the absolute maximum was $41.8 \%$, found in the population SG-26.

Garlic is a vegetable species with a high content of dry matter in the bulb. Dry matter represents one of the basic indicators of garlic quality. Hence, the garlic with higher dry matter content in the bulb is more appreciated. It is stored more easily and used fresh for a longer period. Similarly, it is more desirable in the manufacturing industry. On average, dry matter content in garlic varies depending on the cultivar and growing conditions, from 33 to 47\% (Cantwell et al., 2005; Pardo et al., 2007), which was shown in our research as well. As for our research, the values obtained for this parameter significantly varied per years, indicating that there was the correlation between dry matter content and growing conditions. During more favourable years with more precipitation, when the yield per area unit was higher, the content of dry matter decreased, while during dry years, with more favourable lighting conditions, the content of dry matter increased. Regarding our research, dry matter content varied insignificantly within a population, which points at the significant impact of the genotype on the display of this property (Ovesna et al., 2007).

The average value of essential oil content in the bulb of the observed garlic populations was $0.23 \%$ (Fig. 6). The lowest oil content was determined in the garlic population marked SG-15 and it amounted to $0.183 \%$. The garlic sample from the populations SG-16 and SG-18 had the highest content of oil and the average value was $0.27 \%$. The remaining average values for this property ranged between these two values and they differed at various levels. Four populations (SG-20, SG-8, SG-21 and SG-26) 


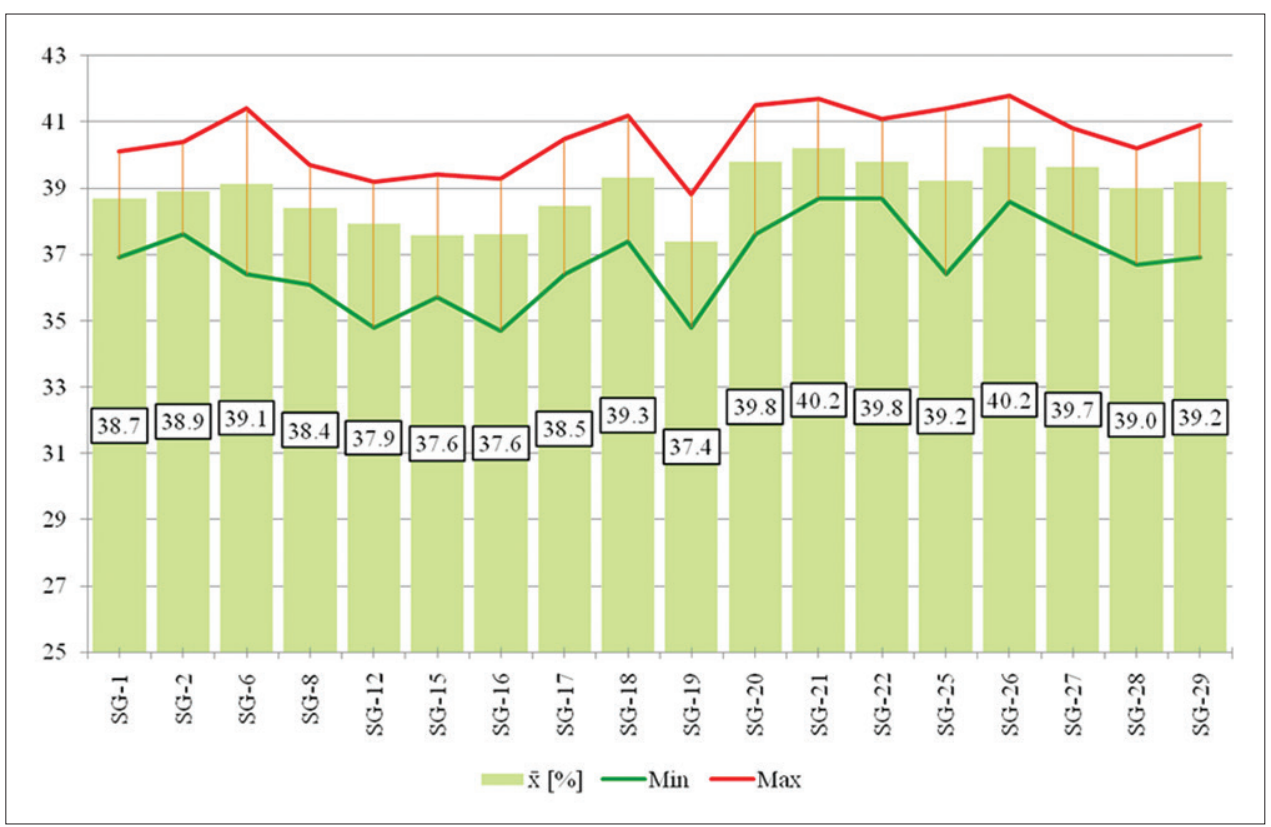

Fig 5. Dry matter content in the bulb [\%], multi-year average. $(\operatorname{LSD}(0.05)=0.53 ; \operatorname{LSD}(0.01)=0.70 ;$ Cv $(\%)=3.1)$.

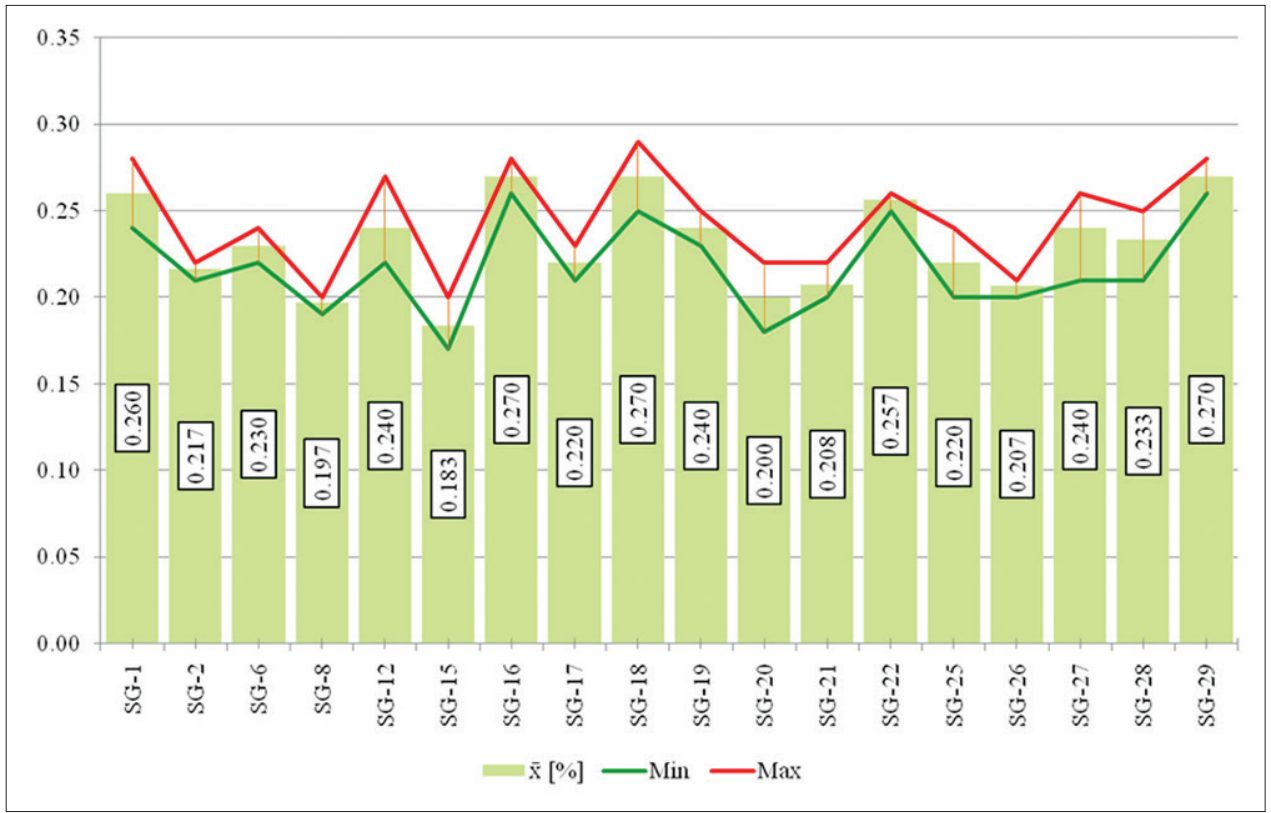

Fig 6. Essential oil content in the bulb [\%], multi-year average. $(\operatorname{LSD}(0.05)=0.025 ; \operatorname{LSD}(0.01)=0.034 ;$ Cv $(\%)=5.0)$.

had the essential oil content which did not statistically differ from the minimum value. Their values ranged from 0.197 to $0.208 \%$. A similar situation was observed in the following 8 populations, where the essential oil content in the bulb had a very narrow range - from 0.22 to $0.24 \%$. Generally, no significant difference was observed between these populations regarding oil content. The highest oil content was determined in the bulbs of the following populations: SG-1, SG22, SG-29, SG-18 and SG-16. The values realized by these populations ranged from $0.257 \%$ to $0.27 \%$ and they did not differ significantly. Furthermore, the comparison of essential oil content in the populations which did not belong to the above mentioned intervals showed a statistically significant difference. In addition, the differences between the groups with the lowest and highest values of essential oil were even extremely significant. The average coefficient of variation for all populations was $5.0 \%$. There were a small number of variations within a population. Namely, the lowest $\mathrm{Cv}$ value was recorded in the garlic SG-22, and the highest in the garlic SG-12. These values were 1.8 and $9.1 \%$, respectively. Further, the absolute minimum and maximum values of essential oil content were found in the samples of the populations SG-15 and SG-18 (0.18\% and $0.29 \%)$. 
The quality of garlic, as a medicinal raw material, is primarily determined by the quantity of essential oil in the bulb. The first official criterion for the quality of the drug Bulbus allii sativi was provided by the VI German pharmacopoeia, which states that the minimum essential oil content must not be less than $0.20 \%$ (Božin, 2009). Essential oil is obtained from fresh garlic cloves by the process of hydrodistillation. The quality of evaporable essential oil ranges from 0.14 to $0.74 \%$ and depends on the genotype, growing conditions, manner of bulb storing, and on the applied distillation method (Haciseferogullari et al., 2005). Importantly, the values of essential oil content obtained in our garlic populations were consistent with the above mentioned values. In addition, the genotypes with more distinctive content of oil than other examined garlic types were underlined. Undoubtedly, the knowledge about the oil content can be helpful in determining some species of the Allium genus. Thus, garlic was classified in group II, with the substantial content of alliin (Fritsch and Keusgen, 2006).

The average value of alliin content for all the examined populations of spring garlic was 3.36\%. Moreover, the average of the values ranged from 0.82 to $4.93 \%$ (Fig. 7). The first, lowest value was defined in the sample of the garlic SG-15, and the highest content of this organosulfur component was registered in the garlic SG-29. Obviously, the population SG-29 had a six times larger value for alliin content than the garlic SG-15. In addition, high values of this property were measured in the populations marked SG-2, SG-16, SG-18, SG-6, SG-1 and SG-26. These values ranged from 3.66 to $4.43 \%$. Nevertheless, seven populations were characterized by the medium alliin content in the bulb, with the values from 3.18 to $3.52 \%$.
The former value was found in the population SG-25 and the latter in the populations SG-8 and SG-28. The bulbs from the populations SG-12 and SG-21 had 3.30 and $3.43 \%$ of alliin. On the other hand, the garlic marked SG-19, SG-22 and SG-17 had low alliin content in the bulb. Their values were $2.18 ; 2.57$ and $2.94 \%$, respectively. The value of alliin content realized by the population SG-19 was the second lowest, but it was 2.65 time higher than the absolute minimum.

The most significant organosulfur compounds, stored within the cytoplasm of the undamaged cell of garlic are alliin, isoalliin and methiin. Alliin is dominant and its content constantly increases in both leaves and the bulb in the process of vegetation. It is the odourless crystalline compound. Damaging the cell structure (chopping, crushing) leads to the transformation of the previous components (under the influence of the enzyme alliinase) into thiosulfinates. The largest part of thiosulfinates is allicin. Allicin is unstable and under the influence of oxygen from the air it is degraded into secondary products which have unpleasant, strong odour, characteristic of garlic. This odour of garlic is mostly from the precursor alliin, and to a lesser degree from isoalliin and methiin. It has been determined that $1 \mathrm{mg}$ of alliin in garlic corresponds to approximately $0.45 \mathrm{mg}$ of allicin (Lanzotti, 2006). A lot of factors have an impact on the content of active organosulfur compounds of garlic, primarily alliin, but the most prominent are the genotype (cultivar), growing conditions and agrotechnology (Schulz, 1998; Cantwell et al., 2005; Montano et al., 2011). Similarly, our research confirmed that the content of alliin significantly varied depending on the garlic population (genotype).

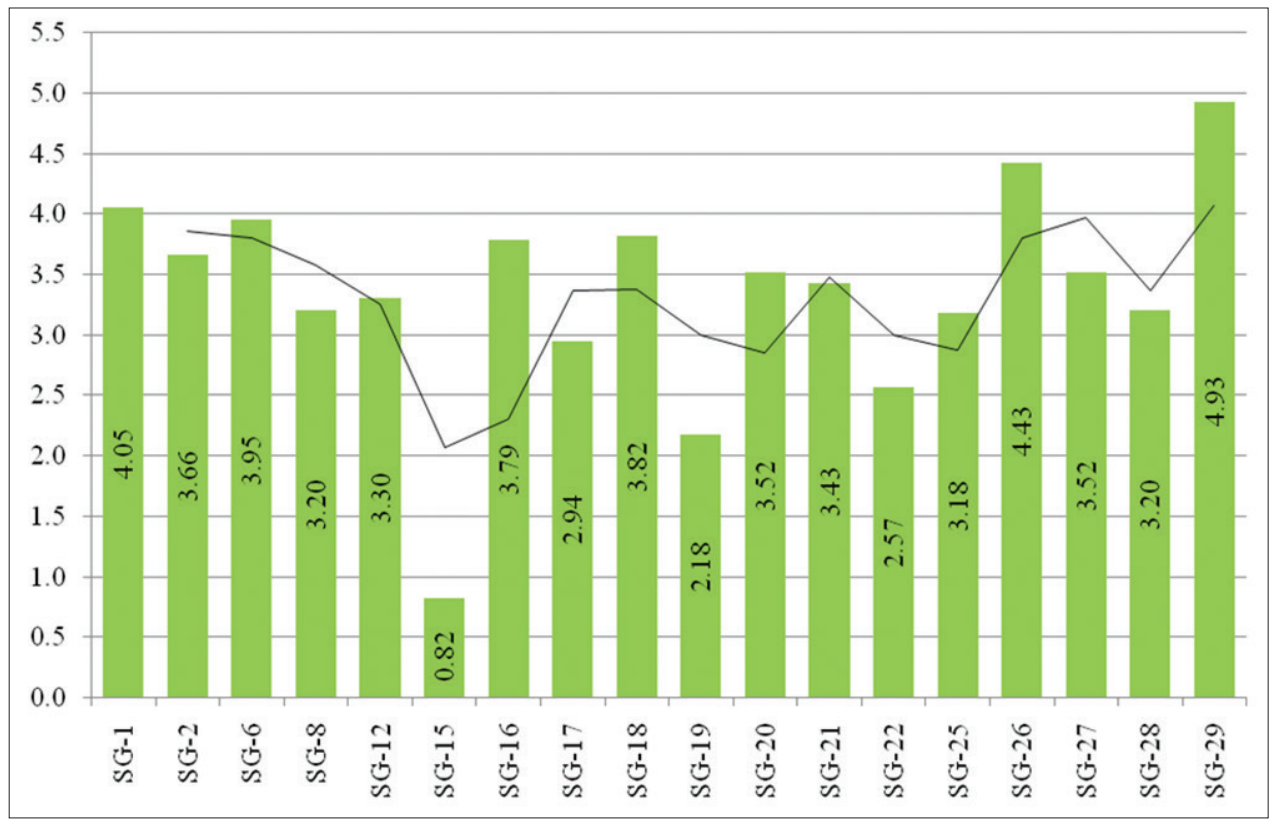

Fig 7. Bulb alliin content [\%]. 


\section{CONCLUSIONS}

It may be claimed that spring garlic, originating from Serbia, has diverse production and chemical characteristics. Thus, it represents a rich selection base. The analysis of the obtained results identified the most promising populations included in the research, with the aim of obtaining (creating) new cultivars of spring garlic. Therefore, the following populations were singled out for obtaining the cultivars of high fertility: SG-18, SG-25, SG-28, SG-16 and SG-29. The populations SG-21 and SG-26 may be promising in relation to technological needs (drying). The populations SG-29, SG-18 and SG-16 can serve as the basis for obtaining the cultivars suitable for the needs of food and pharmaceutical industry. All these can retain their population status, but it cannot be argued that this is the proper direction for improving garlic production in Serbia.

\section{Author contributions}

Designed and conducted all of the experiment (Dj.M. and J.G.V.) Collected data, data analysis, laboratory analysis (Dj.M., N.P. and M.U.). Statistical analysis of the data (J.G.V. and V.T.) and wrote the manuscript (Dj.M.). Reviewed the manuscript (J.G.V.).

\section{REFERENCES}

Ahmad, S. and J. Iqbal. 2002. Optimizing plant density cum weed control method for puccinial rust management and yield in garlic. Asian J. Plant Sci. 1: 197-198.

Božin, B. 2009. Biochemical and Pharmacological Investigations of Species of Genus Allium, L. (Sect. Allium), Ph. D Dissertation, Faculty of Medicine, University of Novi Sad, Republic of Serbia.

Brewster, J. L. 2008. Onions and Other Vegetable Alliums, $2^{\text {nd }}$ ed, CAB International, Wallingford, UK, pp. 27-169.

Burba, J. L. 2009. Garlic (Allium sativum L.) Genetic improvement and seed production. Possibilities of adaptation to variable environments. Rev. Colomb. Cien. Hortícolas. 3: 28-44.

Cantwell, M., G. Hong and R. Voss. 2005. Compositional characterization of a garlic germplasm collection. American Society for Horticultural Science Annual Conference HortScience. Vol. 40. p1039.

Cortes, C. F., F. M. S. Olalla and R. L. Urrea. 2003. Production of garlic (Allium sativum L.) Under controlled deficit irrigation in a semi-arid climate. Agric. Water Manag. 59: 155-167.

Džamić, R., D. Stevanović and M. Jakovljević. 1996. Praktikum iz agrohemije. Nauka, Poljoprivredni fakultet, Beograd, pp. 28-142.

Etoh, T. and P. W. Simon. 2002. Diversity, Fertility and seed production og garlic. In: H. D. Rabinowitch. and L. Currah (Ed.), Allium Crop Science: Recent Advances, Ch. 5, CABI, Wallingford, UK, pp. 101-117.

European Pharmacopoeia IV. 2002. Euroepean Directorate for the Quality of Medicines, Council of Europe, Strasbourg.

FAO. 2015. Statistical Database. Available from: http://www.fao.org/ faostat/agriculture.html.

Figliuolo, G., V. Candido, G. Logozzo, V. Miccolis and P. L. S. Zeuli. 2001. Genetic evaluation of cultivated garlic germplasm (Allium sativum L. and A. ampeloprasum L.). Euphytica. 121: 325-334.

Fritsch, R. M. and M. Keusgen. 2006. Occurrence and taxonomic significance of cysteine sulphoxides in the genus Allium L. (Alliaceae). Phytochemistry. 67: 1127-1165.

Hacıseferogullari, H., M. Ozcan, F. Demir and S. Calısır. 2005. Some nutritional and technological properties of garlic (Allium sativum L.). J. Food Eng. 68: 463-469.

Islam, M. J., M. A. Islam, T. Akter, S. R. Saha, M. S. Alam and M. K. Hasan. 2004. Performance evaluation of some garlic genotypes in Bangladesh. Asian J. Plant Sci. 3: 14-16.

Kamenetsky, R., I. S. London, F. Khassanov, C. Kik, A. W. van Heusden, M. V. van Ginkel, K. Burger-Meijer, J. Auger, I. Arnault and H. D. Rabinowitch. 2005. Diversity in fertility potential and organo-sulphur compounds among garlics from Central Asia. Biodivers. Conserv. 14: 281-295.

Kamenetsky, R., I. L. Shafir, H. Zemahm, A. Barzilay and H. D. Rabinowitch. 2004. Environmental control of garlic growth and florogenesis. J. Am. Soc. Hortic. Sci. 129: 144-151.

Kazakova, A. A. 1978. Luk. Kulturna flora SSSR. Leningrad. p4-16.

Lanzotti, V. 2006. The analysis of onion and garlic. J. Chromatogr. A. 1112: 3-22.

Lawson, L. D. 1996. The composition and chemistry of garlic cloves and processed garlic. In: H. P. Koch. and L. D. Lawson (Ed.), Garlic: The Science and Therapeutic Application of $A$. sativum L. and Related Species, $2^{\text {nd }}$ ed, Williams and Wilkins, Baltimore, pp. 37-108.

Lawson, L. D. and C. D. Gardner. 2005. Composition, stability and bioavailability of garlic products used in a clinical trial. J. Agric. Food Chem. 53: 6254-6261.

Mahmood, T., S. L. Hussain, K. M. Khokhar, M. H. Bhatti and H. Laghari. 2002. Comparative performance of garlic cultivars. Asian J. Plant Sci. 1: 160-161.

Mathew, D., Y. Forer, H. D. Rabinowitch and R. Kamenetsky. 2011. Effect of long photoperiod on the reproductive and bulbing processes in garlic (Allium sativum L.) Genotypes. Environ. Exp. Bot. 71: 166-173.

Mirzaei, R., H. Liaghati and A. M. Damghani. 2007. Evaluating yield quality and quantity of garlic as affected by different farming systems and garlic clones. Pak. J. Biol. Sci. 10: 2219-2224.

Montano, A., V. M. Beato, F. Mansilla and F. Orgaz. 2011. Effect of genetic characteristics and environmental factors on organosulfur compounds in garlic (Allium sativum L.) Grown in Andalusia, Spain. J. Agric. Food Chem. 59: 1301-1307.

Moravčević, D., V. Bjelić, M. Moravčević, J. Gvozdanović-Varga, D. Beatović and S. Jelačić. 2011. The Effect of Plant Density on Bulb Quality and Yield of Spring Garlic (Allium sativum L.). 6. International Symposium on Agriculture, Proceedings, Opatija, Croatia, pp. 554-557.

Ovesna, J., L. Kučera, J. Králová, L. Leišová, H. Stavělíková and J. Velíšek. 2007. Genetic diversity among garlic clones as revealed by aflp, phenotypic descriptors and S-amino acids level. Vegetable Crops Res. Bull. 66: 105-116.

Panthee, D. R., R. B. Kc, H. N. Regmi, P. P. Subedi, S. Bhattarai and J. Dhakal. 2006. Diversity analysis of garlic (Allium sativum L.) Germplasms available in Nepal based on morphological characters. Genet. Resour. Crop Evol. 53: 205-212.

Pardo, J. E., J. Escribano, R. Gomez and A. Alvarruiz. 2007. Physicalchemical and sensory quality evaluation of garlic cultivars. J. Food Qual. 30: 609-622.

Rahman, S., A. Islam, S. Haque and A. Karim. 2004. Effect of planting date and gibberellic acid on the growth and yield of garlic (Allium sativum L.). Asian J. Plant Sci. 3: 344-352. 
Rekowska, E. and K. Skupien. 2007. Influence of flat covers and sowing density on yield and chemical composition of garlic cultivated for bundle-harvest. Vegetable Crops Res. Bull. 66: 17-24.

Republic Hydrometeorological Service of Serbia (RHSS), Republic of Serbia. Available from: http://www.hidmet.gov.rs/index_eng.php.

Schulz, V. 1998. Garlic. In: R. Hansel. and V. E. Tayler (Ed.), Rational Phytotherapy. A Physicians' Guide to Herbal Medicine, $3^{\text {rd }}$ ed,
Springer, Berlin, pp. 107-125.

Zahedi, B., A. K. Kashi, Z. Zamani, G. H. Mosahebi and M. Hassani. 2007. Evaluation of Iranian garlic (Allium sativum L.) Genotypes using multivariate analysis methods based on morphological characteristics. Biotechnology. 6: 353-356.

Živković, M. 1991. Geneza i osobine zemljišta. Pedologija, I-knjiga, Naučna Knjiga, Institut za Pedologiju i Tehnologiju Tla, Beograd. 